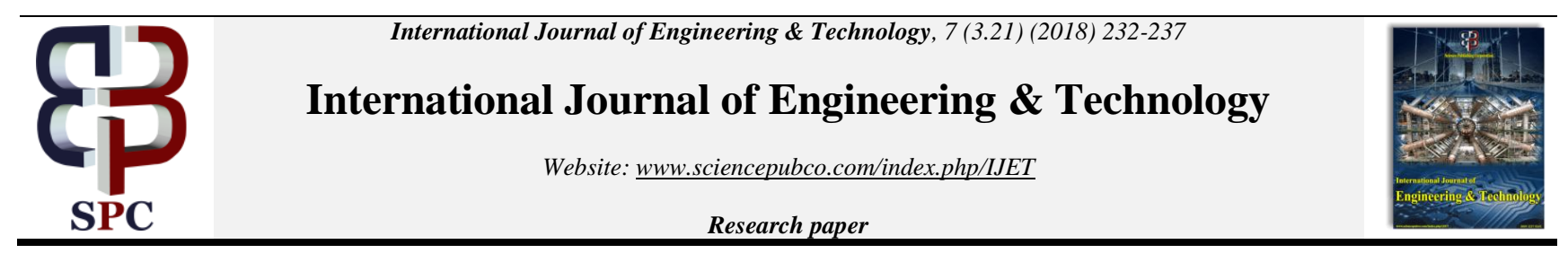

\title{
Mobile Advertising: Behavioural Intention Among Undergraduates in Malaysia
}

\author{
Yeo Sook Fern ${ }^{1}$, Tan Cheng Ling ${ }^{2}$, Lim Kah Boon ${ }^{3 *}$, Stany Wee Lian Fong ${ }^{4}$, Fong Ming Jie \\ 1,3.4,5 Faculty of Business, Multimedia University, Melaka \\ ${ }^{2}$ Graduate School of Business, Universiti Sains Malaysia, Penang \\ *Corresponding author E-mail: kblim@mmu.edu.my
}

\begin{abstract}
In today's world, smartphone has become a necessity in our daily life. All the businesses will take advantage of mobile phone to advertise their product to create awareness. Due to the new techniques and technologies, mobile advertising has become more efficiently (Saadeghvaziri \& Hosseini, 2011). Therefore, we conduct the factors that influence the effects of mobile advertising campaign, especially the case of Short Messaging Service (SMS). According to Yeo, Tan and Lim (2016), mobile technology is growing intensively. Smartphone become more convenience and able to let users to have fun while they experience mobile device shopping, and they able to open many browsers so they can either comparing the price, shopping or purchasing good. The research framework such as the five independent variables (perceived usefulness, perceived ease of use, irritation, credibility, and informativeness) has connected with dependent variable (behavioural intention). This research design has planned to involve 300 respondents. The unit analysis for this study is all undergraduates in Malaysia. A total of 274 undergraduates have participated in this study which comprised of $91 \%$ of the response rate. There are about $21.5 \%$ experiencing the mobile advertising through SMS/MMS. Furthermore, the frequency of the respondent towards these mobile advertisement is approximately $24.5 \%$. The findings revealed that four direct relationships hypothesized namely perceived usefulness, perceived ease of use, credibility and informativeness were significantly related to the behavioural intention towards mobile advertising.
\end{abstract}

Keywords: Perceived usefulness; Credibility; Informativeness; Mobile advertising; Behavioural intention; Malaysia

\section{Introduction}

Advance technologies can enhance communicate among consumers and also understand the needs and wants of the consumers (Ali, Shiraz, Ramezani, \& Shiraz, 2013). In today's world, smart phone already become our necessity goods and use it in daily life. Majority of business tend to focus to promote their products or update their information to consumers towards mobile advertising.

Mobile advertising go one step further to get closer with consumer daily life Tsang, Ho and Liang, (2014). For instance, we can narrow it down the scope of factors and effectiveness like what the effect of mobile advertising compare with other media? How consumers think and suggest about mobile advertising? What is the best way to conduct the most effective for advertising? This is some important issues we need to understand especially we need to know how consumer feels and whether they accepted the mobile advertising or not.

According to the Interactive Mobile Advertising Platform IMAP: Global System Framework- Business Model, Research Report., (2003), definition of mobile advertising as the business of encouraging people to buy products and services using the wireless channel as medium to deliver the advertisement message. Due to the new techniques and technologies, mobile advertising has become more efficiently (Saadeghvaziri \& Hosseini, 2011). Therefore, we conduct the factors that influence the effects of mobile advertising campaign, especially the case of Short Messaging Service (SMS). This is the way can spread the information very fast and effective thru world-of-mouth compare to the offline advertising.

At the same time, the consumer attitudes towards advertising need to be focus by all mobile operators. Previous research has do a research that prove consumer have negative attitudes towards mobile advertising even though there have some latest literature investigated positive attitude towards advertising (Tsang et al., 2014). According to Yeo, Tan and Lim (2016), mobile technology is growing intensively. This is all the factors that we need to pay attention to more about it. In the next section, all the traditional advertising like flyer, banner or television are discuss and adjusted mobile advertising. Thus, this study has been conducted to identify the factors that influence the effectiveness of mobile advertising.

\subsection{Mobile Industry}

Based on previous research, in $2011 \mathrm{~m}$-commerce sales in United State were extended to $\$ 6$ billion with $73 \%$ growth predicted for 2013 , and they expected the trend will continuous extended to $\$ 31$ billion in 2015. While in mobile shopping, there have $93 \%$ of mobile shopping consumers using smart phone in year 2011. According to Williamson (2013), smart phone become more convenience and able to let users to have fun while they experience mobile device shopping, and they able to open many browsers so they can either comparing the price, shopping or purchasing goods. 


\subsection{Situation of Mobile Smartphone}

Based on the research of the year 2014, the landscape of mobile were positively continues growing and majority of U.S. population stated that everyone owns at least a smart phone and Americans will spending around two hours per day on their mobile devices. According to Jones (2014) stated that with $8 \%$ of a user staring at mobile screen while not doing anything, and for mobile marketers it is a good chance to seek for consumer who are finding for local services, and consumers who often purchasing or shopping by using smart phone or device.

Nowadays, majority of trading has been generated by the use of mobile apps. And, mobile apps trading become positively driven the majority of advertising trading and the revenue. One of the trends that we need to concern is that the mobile internet goes worldwide, and the trading has internationalized, it will cause increasing the volume of mobile web interactions. Besides, mobile apps are still liable for the majority share of trading and generation of revenue.

According to Kim and Han (2014), data has reported almost has the same rate of amount in not only in developed countries but also happening in developing countries, and this prove that mobile technology user had become more and more while comparing to other technology (Ali et al., 2013). In other words, mobile commerce already becomes a part of our life and this is an opportunity for business man to do business thru mobile commerce. Mobile advertising become very famous to advertise their company products and services recently. They will advertise at applications, SMS, or get some data from consumers thru some applications to get their general information try to focus niche market.

Mobile advertising began with SMS (Short Message Service), after that reform and innovation to MMS (Multimedia Message Service) were better than SMS that spread the information. And now, technology turn to advance and able advertise in mobile applications. Mobile advertising is more closely to consumer daily life and can be up to date for consumers all the time. The reasons why mobile phones can be very convenience able to communicate at any time in any place, and it also always being open to communication to public, get more attention in one-to-one communication, recording message after responding the message, have the chance to have one-to-one audio-visual communication with others, and providing suitability for customers (SMS) had been very successful (Ünal, Erciş, \& Keser, 2011).

Recent in internet environment, the high perception of mobile device has made a better opportunity for wireless Internet applications such as wireless marketing and online advertising(Tsang et al., 2014). Mobile advertising and Internet advertising have common features to catch consumer attention and deliver the information to consumer such as sounds communication, digital text, pictures and so on. Besides that, it might be more favourable to consumers thru mobile advertising compare to traditional advertising way.

Since mobile phone has become part of a very personal device and it allows users can access it anytime and anywhere, and mobile advertising may take different forms to be more personalized to them(Tsang et al., 2014). The purpose of this study is to identify how the factors and effectiveness will influence the consumer behaviour intention.

\section{Literature Review}

\subsection{Behavioural Intention}

Behaviour is tended to subjective likelihood that he or she will take on in a particular behaviour. Behavioural aim is an activity that particular by the inquiries will be straightforwardly, for example, "I expect to [behaviour]," to distinguish the relative quality of goal. Definition of intention in the Theory of Reasoned Action (TRA) and the Theory of Planned Behaviour (TPB) as: the meas- ure of effort one is willing to apply to accomplish an objective Ajzen, (1991), "behavioural arrangements that...enable achievement of an objective" Ajzen I. , (1996), or simply "proximal objectives" Bandura, A., (1997). Generally, it is intended that the intention of the expected value of tradition, is a conscious process that takes time, it need to require specific consideration the results of target, and focus on the results.

\subsection{Perceived Usefulness}

According to Davis (1989), perceived usefulness is defined "this variable represents the amount of people belief that the use of these new technologies increases their performance." The attitude of the teenagers towards the mobile advertising can be affected by the mobile advertising's perceived usefulness. Usefulness had a relationship intention to have an effect to purchase mechanism such as Internet (Renny \& Siringoringo, 2013). In other words, consumer can ensure the performance that they purchased thru mobile advertising and relying usefulness to help them in many ways. In this study, we determine perceived usefulness extent the performance to $4 \mathrm{G}$ mobile services that will improve the communicational performance. In turn, they also can refer by innovation perception that perceptions towards the innovation itself. Because of this innovation, consumer will more reliable the mobile advertising instead of offline advertising.

Perceived usefulness is used to constructs with the strongest explanation powers to support the mobile advertising (Järnefelt, 2013). According to Hsu, Wang, and Wen (2006), this researcher also found out that the perceived usefulness has the highest to influences the attitudes of the acceptance of mobile coupons. Ducoffe (1995) has mentioned that the determinant of response of consumer is important to communicate the utilitarian advantage of the products' characteristics via advertising. An exploratory study by Lee and Hill, (2013) has uncovered that the sorts of message impact utilitarian view of gifted SMS. As per TAM, the conviction variable saw convenience had an immediate impact on disposition towards reception and in addition to intervene the relationship through perceived usefulness. Moreover, perceived usefulness was found to explain a large amount of variance of attitude towards mobile advertising among young users (Parreño, SanzBlas, Ruiz-Mafé, \& Aldás-Manzano, 2013).

H1: There are relationship between perceived usefulness and behavioural intention towards mobile advertising.

\subsection{Perceived Ease of Use}

According to Davis, (1989), perceived ease of use is the extent to which a consumer trusts that using a technology will be free of exertion. Perceived ease of use alongside with perceived usefulness is the only constructs that impact state of mind in the first Technology Acceptance Model (TAM) framework (Davis, 1989). Nowadays, mobile technology is changing time-to-time, it is necessary to research about consumers' perceived ease of use that will affect the intention of using the latest mobile devices. Perceived ease of use build can likewise be found in IDT theory as difficulty and in Taylor and Todd (1995) work as the ease of use construct. In this research, there is relationship between perceived ease of use and behaviour intention. Moreover, according to Vatanparest, (2010), in mobile phone framework, perceived ease of use, are the factors that impacted toward behavioural intention while using mobile service through mobile application.; Silva, Ratnadiwakara and Zainudeen (2011) stated that always get the latest information advanced mobile advertising.

Past researchers have confirmed that perceived ease of use was in charge in examine the consumers' intention to use of $3 \mathrm{G}$ mobile service (Liao, Tsou and Huang, 2007); Suki, 2012) and perceived ease of use are the most important factor to raise consumer's behavioural intention to use $3 \mathrm{G}$ mobile value-added services and opposite to this, perceived ease of use was not significant with consumers' intention to take on 3G (Chong, Ooi, Lin \& Bao, 
2012). Mobile users' perceived ease of use is the major factors in acceptance of SMS Kim et al., (2009), influenced to use SMS based mobile chatting services Wel, Alam, Omar and Noor (2013) and in moulding users' feelings and expectation to use multimedia messaging services (Kim, Ma \& Park, 2009).

$\mathrm{H}$ 2: There are relationship between perceived ease of use and behavioural intention towards mobile advertising.

\subsection{Irritation}

Irritation can be characterized as a notice that produces irritation, discontent, and brief bigotry (Aaker \& Donald, 1985). A little irration can decrease the adequacy of publicizing. Irritation can be brought on by the focal merchandise itself or by commercials thought to be controllable or be cheated in the same way (Chakrabarty \& Yelkur, 2005). Customers suspecting that publicizing were utilizing irritating, complex, or culpable procedures as irritating. This diminishes the irritation made by intrusion on the grounds that the advertisement is an agreement between promoter and collector, where the collector chooses when and the amount of data to get (Saadeghvaziri and Hosseini, 2011; Bauer, Reichardt, Barnes, \& Neumann, 2005). Advertisement can be seen as spam in the event that they are tedious, hindering during buyers every day exercises, overpowering with data or the recurrence is too high (Christensen, 2013).

Besides, the publicizing of irritation also can be saying that have a prescient about the value of Internet will be increase stated by Brackett and Carr, (2001) and versatile advertising mention by Haghirian et al., (2005). The attitude of consumer toward web publicizing is adversely identified with the irritation through the advertising of web (Chakrabarty \& Yelkur, 2005). Plus, irritation likewise can manual for a knowingly diminishment for the value that can bring by the crowd. As indicated by Lin et al., (2012) this is particularly the situation where promoters' utilizes procedures that irritate outrage, offend or are excessively manipulative for the shoppers.

H3: There are relationship between irritation and behavioural intention towards mobile advertising.

\subsection{Credibility}

According to MacKenzie and Lutz, (1989), advertisement credibility defines as "the extent to which the consumer perceives claims made about the brand in the ad (advertisement) to be truthful and believable." According to Christensen (2013), advertising credibility need to be concern on measured through the content the advertisement delivers and is considered important, when consumers have to decide or deals on the basis of uncertain information. In other words, consumer will evaluate the service is it really truthful by using credibility and their pass experience to decide to choose the advertising channel. Experience can shows that advertising channels to boost the credibility of advertising to get through it; however the credibility might vary by mediums. A study found that information on the Internet get less credibility than a printed information unless it is conveyed by a strong brand (Liu et al., 2012) (Haghirian and Madlberger, 2005).

Credibility has proved to importantly influence the value of advertising, because advertising are determined by their truthfulness and believability. Based on the previous research had distinguished a positive connection between consumers impression of the credibility of the ad and consumers perspective toward the advertisement (Zabadi, Shur, \& Elsayed, 2012). Besides, credibility and infotainment have been proved by Liu et al., (2012) as having an effect on advertising value regardless the cultural background. Consequently, when the message is sent from their familiar marketers, customers believe that the advertising message is trustworthy and they focus more on that message content rather than unfamiliar marketers (Abeywickrama \& Vasickova, 2014).

H4: There are relationship between credibility and behavioural intention towards mobile advertising.

\subsection{Informativeness}

Informativeness is defined as the ability of advertising to inform consumers of product alternatives with the goal that buys yielding the best conceivable fulfilment can be made (Ducoffe, 1995),. A feature of informativeness is can help advertising providing helpful information. Informativeness depends on the cooperation between users and content provided by the information needs of mobile services (Christensen, 2013). To make sure the accuracy of informativeness, it will provide the information with meaningfulness and appropriateness and would produce a higher quality of perceived information (Wang \& Lin,2012). Towards the day's end the essence of promotion's significance will builds the quality of the data and accordingly the perceived informativeness of the advertisement. Based on the previous studies have state that informativeness of advertisements is strongly connected with the value of advertising, when it is concern the attitude and transferred thru traditional media (Zabadi et al., 2012).

Informativeness is considered a valuable incentive in mobile advertising because the reaction of the receiver is positively advertising when the advertising to provide users with a variety of resources and useful information (Lin et al., 2012). Assume the integral part of the nature of the data, in order to meet consumer needs and desires. According to Bauer et al., (2005), if the advertising meets the needs and wants of users of information and knowledge about services or products, it can be assumed that advertising will benefit to consumer perception. The important required to be met by demands of recipients is quality of the information.

H5: There are relationship between informativeness and behavioural intention towards mobile advertising.

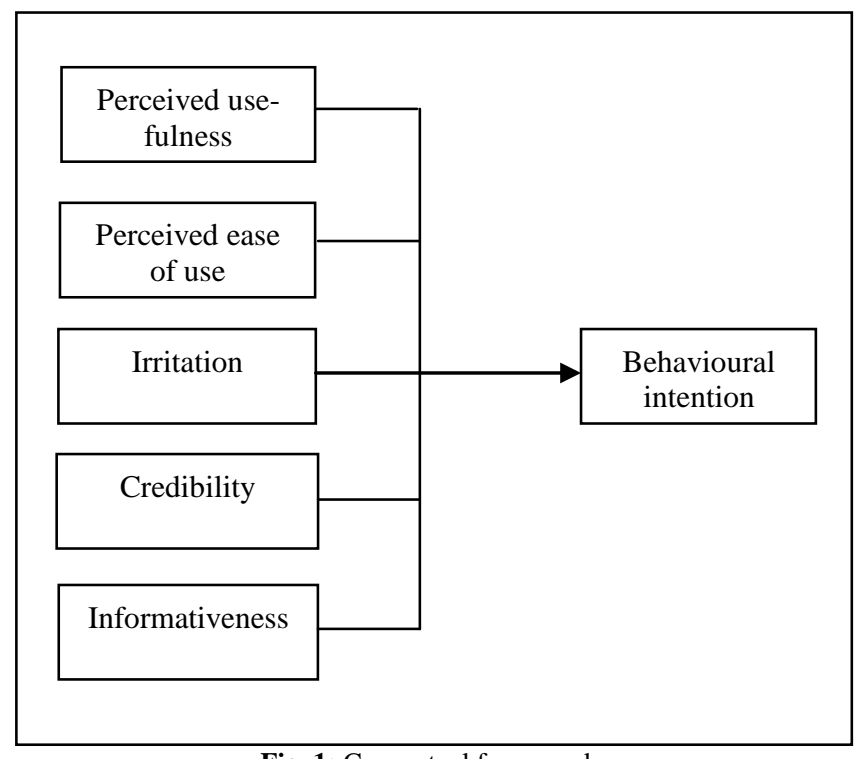

Fig. 1: Conceptual framework.

\section{Methodology/Materials}

\subsection{Sample and Data Collection}

This study used the purposive sampling and the unit analysis for this study is undergraduates in Malaysia higher education. A selfadministered questionnaire was used in this study. A total of 300 questionnaires were distributed to the targeted respondents in the southern part of Malaysia.

\subsection{Measurement and Analysis}

The survey was collected between November 2015 and January 2016. Using the drop-off, pick-up method, the researchers visited 
every higher learning institutions to explain the purpose of the survey to the Student Affairs Department and to later collect the responses. The questionnaires are divided into two sections namely; Section A comprise of respondents' background such as gender, age, race, income level, and their experiences in using mobile advertising, and Section B consists of the measurement items for the variables stated in the conceptual framework which consists of 33 items were developed to measure the construct and it's dimensions. All measures used in this study were adapted from existing scales; perceived usefulness and perceived ease of use (Knight \& Burn, 2011); informativenss (Chowdhury, Parvin, Weitenberner \& Becker, 2006); credibility (Liu et al., 2012); irritation and behavioural intention (Unal, Erci, \& Keser, 2011). Respondents responded to the items using a 5-point Likert-type scale with " 1 ", $=$ "strongly disagree" "to " $5 "$ " = "strongly agree".

In this study, reliability analysis was used to measure the consistency and stability of a scale. According to Sekaran, (2003) said that the higher the reliability coefficients, the better the measuring instrument. Cronbach Alpha values will be evaluate in 5 scale which is $\alpha \geq 0.9$ represented as excellent, $0.7 \leq \alpha<0.9$ represented as good, $0.6 \leq \alpha<0.7$ represented as acceptable, $0.5 \leq \alpha<0.6$ represented as poor, and $\alpha<0.5$ represented as unacceptable. As shown in Table 1, all the Cronbach's alpha values of the independent and dependent variables are in the accepted reliability range from 0.776 to 0.850 . Therefore, the results confirm that all the six variables are in the acceptable range. The highest Cronbach's Alpha value is from perceived usefulness which was recorded at 0.850 and irritation has the smallest Cronbach's Alpha value of 0.776 .

Table 1: Reliability Analysis for Independent and Dependent Variables

\begin{tabular}{|l|c|}
\hline \multicolumn{1}{|c|}{ Variables } & Cronbach's Alpha \\
\hline Perceived Usefulness & 0.850 \\
\hline Perceived Ease of Use & 0.842 \\
\hline Irritation & 0.776 \\
\hline Credibility & 0.845 \\
\hline Informativeness & 0.837 \\
\hline Behavioural Intention & 0.807 \\
\hline
\end{tabular}

\section{Results and Findings}

\subsection{Sample Profile}

A total of 274 undergraduates have participated in this study which comprised of $91 \%$ of the response rate. However, 26 questionnaires went missing. There are about $21.5 \%$ experiencing the mobile advertising through SMS/MMS. Furthermore, the frequency of the respondent towards these mobile advertisement is approximately $24.5 \%$. Among the respondents $56.9 \%$ are male and $43.1 \%$ are female. Majority of the respondents are from the Chinese community $(56.6 \%)$ and about $10 \%$ of them are actively involved with the mobile advertising. The majority age of respondents is between $21-25$ years old (61.3\%) and followed by 26-30 years old $(20.8 \%)$.

\subsection{Result of Hypotheses Tests}

Multiple regression analysis is used to determine the relationship between the five independent variables and dependent variable. The result showed that this model is significant at $5 \%$ significance level with $\mathrm{F}$ - value of 312.098 . The $\mathrm{R}$ - square value as shown is 0.85 and this indicates that $85 \%$ behavioural intention can be defined by the independent variables such as perceived usefulness, perceived ease of use, irritation, credibility, and informativeness. Table 2 shows the multiple regression analysis result of this study. The findings revealed that four direct relationships hypothesized namely perceived usefulness, perceived ease of use, credibility and informativeness were significantly related to the behavioural intention towards mobile advertising except irritation.
Table 2: Multiple Regression Analysis Result

\begin{tabular}{|l|c|c|}
\hline \multicolumn{1}{|c|}{ Variables } & p - value & Hypothesis Result \\
\hline Perceived Usefulness & 0.048 & Supported \\
\hline Perceived Ease of Use & 0.034 & Supported \\
\hline Irritation & 0.350 & Not supported \\
\hline Credibility & 0.000 & Supported \\
\hline Informativeness & 0.000 & Supported \\
\hline
\end{tabular}

$\mathrm{R}^{2}=0.85$

$\alpha=0.05$

Table 2 shows that the relationship between perceived usefulness and customers' behavioural intention is significant. The $p$-value of perceived usefulness variable is 0.048 which was lower than 0.05 alpha levels. This result has shown that there has significant relationship between perceived usefulness and customers' behavioural intention. The reliability of perceived usefulness was 0.851 and it was greater than 0.7 showed the high strength of association. The results from this study is found to be consistent with Muk and Chung (2015) where they found that respondents with positive attitudes toward the advertising of SMS easily influenced by their own perceptions in terms of perceived usefulness.

Perceived ease of usefulness is determined as one of the important factor in predicting behavioural intention towards mobile advertising. The $p$-value of perceived ease of use variable is 0.034 which is lower than 0.05 alpha levels. Obviously, this output stated that there has significant relationship between perceived ease of use and customers' behavioural intention. According to Soroa-Koury (2008), advertising need to be relevant and must be able to offer in a tangible value then it will lead to consumers' willingness adopt to mobile advertising.

As for the third hypothesis, the p-value of irritation variable obtained 0.350 which is greater than 0.05 alpha levels. Thus, the result showed that there have no significant effect and relationship between irritation and bahavioural intention. Most of the company make consumers feels irritated and distributes is because they are using the wrong marketing tactics (Rittippant, Witthayawarakul, Limpiti, \& Lertdejdecha, 2009). Correspondingly, Tsang, Ho, and Liang (2004), found that there is negative correlation between irritation and behavioural intention and attitudes of consumers towards mobile advertising in the studies. In other words, irritation, offending advertising tactics might lead consumers to identify the advertisement which is annoying and irritating.

This study also found that there is a significant relationship in between credibility and customers' behavioural intention. Therefore, the fourth hypothesis is supported. The p-value of credibility variable is 0.000 which is lower than 0.05 alpha values. This study is consistent with Chowdhury et al., (2006) findings. They found that there is a positive attitude effecting the usage of mobile devices to promote their products and services through mobile advertising. Furthermore, Choi and Rifon (2002) also found out the corporate credibility has a significant relationship between attitude towards the advertisements, the brand and behavioural intention.

Last but not least, the fifth hypothesis is found to be supported. The predictor for informativeness has the $\mathrm{p}$-value of 0.000 which is lower than 0.05 alpha values. This has proven that informativeness has an effect towards behavioural intention. Based on the previous studies, Ünal, Ercis and Keser (2011) stated that informativeness are able to provide the information that up-to-date, timely and can be access easily. These features of informativeness can affect the satisfaction of consumer and their buying decisions. Similarly, Yoo and Han, (2014) found that customers will concentrate on the message through the mobile advertising and won't miss any information regarding the product been promote.

\section{Conclusion}

The aim of this study was to examine the factors affecting behavioural intention of undergraduates in Malaysia towards mobile advertising. In general, the results shows that perceived usefulness, perceived ease of use, credibility and informativeness were signif- 
icantly related to the behavioural intention towards mobile advertising and remaining hypotheses were not supported is the relationship between irritation and behavioural intention. Through this study, the retailers in the iservice industry will benefits through the functions of mobile advertising. The function of the mobile marketing as a tool is expected to make improvement for activities in retailers' value chain as communications between consumer and retailer, interactions of services and sales, higher margin and improvement the outcome of output value. Therefore, there is a need for the retailers to understand which factors is of importance to the users whereby in this context is the undergraduates in Malaysia.

\section{References}

[1] Aaker, D.A \& Donald, E.B. (1985). Causes of irritation in advertising. Journal of Marketing, 47-57.

[2] Abeywickrama, M. \& Vasickova, J. (2014). Attitude towards mobile advertising and purchase intention of Swedish customers : A quantitative study on the impact of message content and flow experience. Spring Semester

[3] Ajzen. (1991). The theory of planned behavior. Organizational Behavior and Human Decision Processe. 50(2), 179-211.

[4] Ajzen, I. (1996). The moderating effects of attitude in decision making. The Psychology of Action: Linking Cognition and Motivation to Behavior .

[5] Muk, A. \& Chung, C. (2015). Applying the technology acceptance model in a two-country study of SMS advertising. Journal of Business Research. 68 (1), 1-6.

[6] Ali, M., Shiraz, E., Ramezani, E., \& Shiraz, M. A. E. (2013). Investigation of effective factors in using mobile advertising in Andimeshk. Kuwait Chapter of the Arabian Journal of Business and Management Review. 2(5), 149-156.

[7] Bandura, A. (1997). Self-efficacy: The xercise of control. New York : Freeman

[8] Bauer, H. H., Reichardt, T., Barnes, S. J., \& Neumann, M. M. (2005). Driving consumer acceptance of mobile marketing: a theoretical frame work and empirical study. Journal of Electronic Commerce Research, 6 (3), 181-191.

[9] Brackett, L.K. \& Carr, B.N. (2001). Cyberspace advertising vs. other media: Consumer vs. mature student attitudes. Journal of Advertising Research , 41 (5), 23-32.

[10] Chakrabarty, S. \& Yelkur, R. (2005). The effects of ad irritation on brand attitudes. Journal of Promotion Management , 11 (2/3), 37-48.

[11]Choi, S.M. \& Rifon, N.J.. (2002). Antecedents and consequences of Web advertising credibility: A study of consumer response to banner ads. Journal of Interactive Advertising, 3 (1), 12-24.

[12]Chong, A.Y.L., Ooi, K.B., Lin, B. \& Bao, H.J. (2012). An empirical analysis of the determinants of $3 \mathrm{G}$ adoption in China. Computers in Human Behavior. 28(2), 360-369.

[13] Chowdhury, H. K., Parvin, N., Weitenberner, C., \& Becker, M. (2006). Consumer Attitude Toward Mobile Advertising in An Emerging Market: An Emprirical Study. International Journal of Mobile Advertising, 1 (2), 33-42.

[14]Christensen, P. (2013) Adoption of mobile advertising in Denmark Investigating psychological factors affecting consumers intention to adopt mobile advertising from MNO's. Aarhus University: Denmark, 1-93.

[15]Davis, F. D. (1989). Perceived Usefulness, Perceived Ease of Use, and User Acceptance of Information Technology. IT Usefulness and ease of use , 319-340.

[16]Ducoffe, R.H. (1995). How consumer assess the value of advertising. Journal of Current Issues and Research in Advertising, 1-18.

[17]Haghirian, P. \& Madlberger, M.. (2005). Consumer attitude toward advertising via mobile devices - an empirical investigation among austrian users. . ECIS Regensburg, 447-458.

[18]Hsu, T., Wang, Y. \& Wen, S. (2006). Using the decomposed theory of planned behaviour to analyse consumer behavioural intention towards Mobile text message coupons. Journal of Targeting , 309324.

[19]IMAP: Global System Framework- Business Model, Research Report. (2003). Retrieved from Global System FrameworkBusiness Model, Research Report.: http://www.imapproject.org/imapproject/downloadroot/public1/D2. $1 . b \% 206 \% 2002 \% 2003 . p d f$
[20]Järnefelt, P. (2013). An empirical study on the adoption of mobile location-based advertising, 1-55.

[21]Jones, K. (12 February, 2014). The 2014 Mobile Landscape: 25 Statistics That Will Drive The Future of Mobile Marketing [Infographic]. Retrieved from http://www.searchenginejournal.com/2014-mobile-landscape-25statistics-will-drive-future-mobile-marketing-infographic/89507/

[22] Kim, Y. J., \& Han, J. (2014). Why smartphone advertising attracts customers: A model of Web advertising, flow, and personalization. Computers in Human Behavior, 33, 256-269.

[23] Kim, J., Ma, Y.J. \& Park, J. (2009). Are US consumers ready to adopt mobile technology for fashion goods?: An integrated theoretical approch. Journal Fashion Marketing Management , 13, 215-230

[24] Knight, S., \& Burn, J. (2011). Introducing the OTAM: exploring users' perceptions of their on-going interaction with adopted technologies. Australasian Journal of Information Systems, 17 (1), 5-41.

[25]Lee, H.H. \& Hill, J.T.. (2013). Utilitarian and hedonic perceptions of short message service mobile marketing. International Journal of Mobile Communication, 11 (6), 597-616.

[26]Liao, C.H., Tsou, C. W. \& Huang, M. F. (2007). Factors influencing the usage of $3 \mathrm{G}$ mobile services in Taiwan. Online Information Review, 31 (6), 759-774.

[27]Liu, C.L.E, Rudolf, R.S., Noemi,P. \& Parissa, H. (2012). Determinants of consumer perceptions toward mobile advertising a comparison between Japan and Austria. Journal of Interactive Marketing, 26, 21-32.

[28] MacKenzie \& Lutz. (1989). An empirical examination of the structural antecedents of attitude toward the ad in an advertising pretesting context. Journal of Marketing , 48-65.

[29]Parreño, J. M., Sanz-Blas, S., Ruiz-Mafé, C., \& Aldás-Manzano, J. (2013). Key factors of teenagers' mobile advertising acceptance. Industrial Management \& Data Systems, 113(5), 732-749.

[30] Renny, G.S.,\&Siringoringo, H. (2013). Perceived usefulness, ease of use, and attitude towards online shopping usefulness towards online airlines ticket purchase. Social and Behavioural Sciences , 212-216.

[31] Rittippant, N., Witthayawarakul, J., Limpiti, P. \& Lertdejdecha, N. (2009). Consumers' perception of the effectiveness of short message service (SMS) and multimedia message service (MMS) as marketing tools. Procedings of World Academy of Science Engineering and Technology, 815-821.

[32] Saadeghvaziri, F., \& Hosseini, H. K. (2011). Mobile advertising: An investigation of factors creating positive attitude in Iranian customers. African Journal of Business Management, 5(2), 394 404.

[33] Sekaran. (2003). Research methods for business. A skill building approach. New York: Wiley.

[34] Ünal S., Ercis A. \& Keser E. (2011). Attitudes towards mobile advertising $-A$ research to determine the differences between the attitudes of youth and adults. Procedia Social and Behavoral Science, 24, 361-377.

[35] Silva, H. d., Ratnadiwakara, D. \& Zainudeen, A. (2011). Social influence in mobile adoption: evidence from the bottom of the pyramid in emerging Asia. Information Technology and International Development, 7(3), 1-18.

[36] Soroa-Koury, S., (2008). Consumers' responses to mobile advertising a normative social behaviour perspective. Ths of U. Texas at El Paso. UMI, 1453834

[37] Suki, N. M. (2012). Third generation (3G) mobile service acceptance: Evidence from Malaysia. African Journal of Business Management, 6(15), 5165-5171.

[38] Taylor, S., \& Todd, P. A. (1995). Understanding Information Technology Usage: A Test of Competing Models. Information System Research , 144-176.

[39] Tsang, M. M., Ho, S. \& Liang, T (2014). Consumer Attitudes toward Mobile Advertising: An Empirical Study, International Journal of Electronic Commerce 8(3), 65-78.

[40] Ünal, S., Erciş, A., \& Keser, E. (2011). Attitudes towards mobile advertising - A research to determine the differences between the attitudes of youth and adults. Procedia - Social and Behavioral Sciences, 24, 361-377.

[41]Wang,K. \& Lin, C. (2012). The adoption of mobile value-added services: Investigating. Managing service quality, 184-208.

[42]Wel, C.A.C, Alam, S.S., Omar, N.A. \& Noor, S.M. (2013). Students intention to use mobile chatting services in Malaysia. International Proceeding Economics Devevelopment \& Research, 50, 128-132. 
[43] Williamson, M.. (1 February, 2013). The Mobile Industry 2012 2015 - Overview, Trends and Predictions. Retrieved from bianor: http://www.bianor.com/blog/the-mobile-industry-2012-2015-

overview-trends-and-predictions/

[44] Yeo, S.F., Tan, C.L., \& Lim, J.Q. (2016). Mobile marketing acceptance: empirical evidences among undergraduates in Malaysia. Information, International Information Institute, 19 (8A), 3263 3270 .

[45] Yoo, J.K. \& Han, J.Y. (2014). Computers in Human Behavior. Why smartphone advertising attracts customers: A model of Web advertising flow, and personalization , 256-269.

[46]Zabadi, A., Shur, M., \& Elsayed, E. (2012). Consumer attitudes toward SMS advertising among Jordanian users. International Journal Of Marketing Studies , 4(1), 77-94. 